Article

\title{
Fluoroalkyl Pentacarbonylmanganese(I) Complexes as Initiators for the Radical (co)Polymerization of Fluoromonomers
}

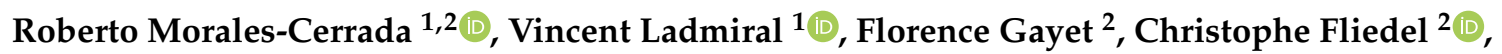 \\ Rinaldo Poli $2, *$ (D) and Bruno Améduri 1,*(D) \\ 1 Institut Charles Gerhardt Montpellier, University of Montpellier, CNRS, ENSCM, Place Eugène Bataillon, \\ 34095 Montpellier CEDEX 5, France; roberto.morales-cerrada@enscm.fr (R.M.-C.); \\ vincent.ladmiral@enscm.fr (V.L.) \\ 2 Laboratoire de Chimie de Coordination (LCC), Université de Toulouse, CNRS, UPS, INPT, 205 route de \\ Narbonne, BP 44099, 31077 Toulouse CEDEX 4, France; florence.gayet@ensiacet.fr (F.G.); \\ christophe.fliedel@lcc-toulouse.fr (C.F.) \\ * Correspondence: rinaldo.poli@lcc-toulouse.fr (R.P.); bruno.ameduri@enscm.fr (B.A.); \\ Tel.: +33-(0)5-61-33-31-73 (R.P.); +33-(0)4-67-14-43-68 (B.A.)
}

Received: 17 December 2019; Accepted: 4 February 2020; Published: 8 February 2020

\begin{abstract}
The use of $\left[\mathrm{Mn}\left(\mathrm{R}_{\mathrm{F}}\right)(\mathrm{CO})_{5}\right]\left(\mathrm{R}_{\mathrm{F}}=\mathrm{CF}_{3}, \mathrm{CHF}_{2}, \mathrm{CH}_{2} \mathrm{CF}_{3}, \mathrm{COCF}_{2} \mathrm{CH}_{3}\right)$ to initiate the radical polymerization of vinylidene fluoride $\left(\mathrm{F}_{2} \mathrm{C}=\mathrm{CH}_{2}, \mathrm{VDF}\right)$ and the radical alternating copolymerization of vinyl acetate $\left(\mathrm{CH}_{2}=\mathrm{CHOOCCH}, \mathrm{VAc}\right)$ with tert-butyl 2-(trifluoromethyl)acrylate (MAF-TBE) by generating primary $\mathrm{R}_{\mathrm{F}} \bullet$ radicals is presented. Three different initiating methods with $\left[\mathrm{Mn}\left(\mathrm{CF}_{3}\right)(\mathrm{CO})_{5}\right]$ (thermal at ca. $100{ }^{\circ} \mathrm{C}$, visible light and UV irradiations) are described and compared. Fair (60\%) to satisfactory (74\%) polyvinylidene fluoride (PVDF) yields were obtained from the visible light and UV activations, respectively. Molar masses of PVDF reaching 53,000 $\mathrm{g} \cdot \mathrm{mol}^{-1}$ were produced from the visible light initiation after $4 \mathrm{~h}$. However, the use of $\left[\mathrm{Mn}\left(\mathrm{CHF}_{2}\right)(\mathrm{CO})_{5}\right]$ and $\left[\mathrm{Mn}\left(\mathrm{CH}_{2} \mathrm{CF}_{3}\right)(\mathrm{CO})_{5}\right]$ as radical initiators produced PVDF in a very low yield ( 0 to $7 \%$ ) by both thermal and photochemical initiations, while $\left[\mathrm{Mn}\left(\mathrm{COCF}_{2} \mathrm{CH}_{3}\right)(\mathrm{CO})_{5}\right]$ led to the formation of PVDF in a moderate yield (7\% to $23 \%$. Nevertheless, complexes $\left[\mathrm{Mn}\left(\mathrm{CH}_{2} \mathrm{CF}_{3}\right)(\mathrm{CO})_{5}\right]$ and $\left[\mathrm{Mn}(\mathrm{COCHF})(\mathrm{CO})_{5}\right]$ efficiently initiated the alternating VAc/MAF-TBE copolymerization. All synthesized polymers were characterized by ${ }^{1} \mathrm{H}$ and ${ }^{19}$ F NMR spectroscopy, which proves the formation of the expected PVDF or poly(VAc-alt-MAF-TBE) and showing the chaining defects and the end-groups in the case of PVDF. The kinetics of VDF homopolymerization showed a linear $\ln [\mathrm{M}]_{0} /[\mathrm{M}]$ versus time relationship, but a decrease of molar masses vs. VDF conversion was noted in all cases, which shows the absence of control. These PVDFs were rather thermally stable in air (up to $410^{\circ} \mathrm{C}$ ), especially for those having the highest molar masses. The melting points ranged from 164 to $175^{\circ} \mathrm{C}$ while the degree of crystallinity varied from $44 \%$ to $53 \%$.
\end{abstract}

Keywords: fluoropolymers; manganese complexes; nuclear magnetic resonance; radicals; organometallic-mediated radical polymerization; vinylidene fluoride

\section{Introduction}

Polyvinylidene fluoride (PVDF) [1-5] is the most produced fluoropolymer after polytetrafluoroethylene (PTFE). This specialty polymer has many relevant properties such as chemical inertness to strong acid and apolar solvents, ferroelectric, pyroelectric, and piezoelectric (when stretched) properties, as well as thermal and electrochemical resistances. It can be involved in many applications such as a binder and separator for lithium ion batteries, paints and coatings, piezoelectrical devices, water purification membranes, and more. 
PVDF is usually prepared by radical polymerization of vinylidene fluoride (VDF), which is known to proceed mainly by head-to-tail monomer additions to afford "head" radicals, $\operatorname{PVDF}_{\mathrm{H}} \bullet$. The occasional (ca. 3\%-5\%) head-to-head additions to afford "tail" radicals, $\mathrm{PVDF}_{\mathrm{T}}{ }^{\circ}$, are immediately followed by a tail-to-tail addition to regenerate $\operatorname{PVDF}_{\mathrm{H}}{ }^{\bullet}$ [6-8]. Reversible-deactivation radical polymerization (RDRP) of VDF has been possible via iodine transfer polymerization (ITP) [3,9-13] and, more recently, by reversible addition-fragmentation chain-transfer (RAFT) polymerization [14,15] and by organometallic-mediated radical polymerization (OMRP) $[16,17]$. Specifically, OMRP is based on the reversible trapping of the growing radical chain by a transition metal complex to generate an organometallic dormant species [18-21]. ITP and RAFT led to a loss of control once the inverted monomer additions led to the full conversion of the dormant species to the tail isomer, respectively $\mathrm{PVDF}_{\mathrm{T}}-\mathrm{I}$ and $\mathrm{PVDF}_{\mathrm{T}}$-xanthate, which are less easily reactivated than the corresponding $\mathrm{PVDF}_{\mathrm{H}}-\mathrm{I}$ and $\mathrm{PVDF}_{\mathrm{H}^{-} \mathrm{xanth}}$ ate species. Conversely, the OMRP technique does not suffer from this problem when the controlling complex is [Co(acac $)_{2}$ ] because both dormant species are reactivated at similar rates [16], which is in agreement with predictions based on the density functional theory (DFT) calculations of the homolytic bond strengths [22].

Asandei et al. have demonstrated the utility of $\left[\mathrm{Mn}_{2}(\mathrm{CO})_{10}\right]$ in ITP in the presence of visible light irradiation because the photolytically produced $\left[\mathrm{Mn}(\mathrm{CO})_{5}{ }^{\circ}\right]$ radicals are able to abstract the iodine atom from the less reactive $\mathrm{PVDF}_{\mathrm{T}}-\mathrm{I}$ dormant species $[3,13]$. There is a question, however, about the possible direct trapping of the $\mathrm{PVDF}_{\mathrm{H}}{ }^{\bullet}$ and $\mathrm{PVDF}_{\mathrm{T}}{ }^{\bullet}$ chains to form (CO) $)_{5} \mathrm{Mn}$-capped organometallic dormant chains and about the possible reactivation of such intermediates. Although the (CO) $)_{5} \mathrm{Mn}$-PVDF bonds are predicted to be considerably stronger than the (acac) ${ }_{2}$ Co-PVDF ones [22], their formation and subsequent thermal and/or photochemical reactivation may constitute an additional mechanism for controlling the polymerization, i.e., by OMRP. Therefore, we have recently embarked in synthetic and experimental bond dissociation enthalpy $(\mathrm{BDE})$ determinations for a series of $\left[\mathrm{Mn}\left(\mathrm{R}_{\mathrm{F}}\right)(\mathrm{CO})_{5}\right]$ complexes where $\mathrm{R}_{\mathrm{F}}$ stands for $\mathrm{CF}_{3}(\mathbf{1}), \mathrm{CHF}_{2}(2), \mathrm{CH}_{2} \mathrm{CF}_{3}(3)$, and $\mathrm{CF}_{2} \mathrm{CH}_{3}$ (4) with the purposes of (i) providing an experimental benchmark to validate the DFT calculations and (ii) testing the possible action of these complexes as initiators in OMRP [23]. This investigation has revealed that the complex with the highest Mn- $R_{F} B D E$ is $\mathbf{1}$ for which the kinetic activation enthalpy is $\Delta H_{\exp }=53.8 \pm 3.5 \mathrm{kcal} \cdot \mathrm{mol}^{-1}$. This value is very close to the DFT-calculated one $\left(55.1 \mathrm{kcal} \cdot \mathrm{mol}^{-1}\right)$. The other determined values are also in line with the DFT predictions (for 2: $\Delta H_{\exp }=46.3 \pm 1.6 \mathrm{vs.} \Delta H_{\mathrm{DFT}}=48.0 \mathrm{kcal} \cdot \mathrm{mol}^{-1}$; for 3 : $\Delta H_{\text {exp }}=50.6 \pm 0.8$ vs. $\Delta H_{\text {DFT }}=50.5 \mathrm{kcal} \cdot \mathrm{mol}^{-1}$ ). Compound 4 could not be isolated in a sufficiently pure state for an experimental measurement of the BDE, whereas the DFT calculations suggest that it should contain a homolytically weaker bond $\left(46.0 \mathrm{kcal} \cdot \mathrm{mol}^{-1}\right)$ [22]. However, its acyl precursor, $\left[\mathrm{Mn}\left(\mathrm{COCF}_{2} \mathrm{CH}_{3}\right)(\mathrm{CO})_{5}\right]$ (5), could be obtained as a pure crystalline solid [23]. The inability to isolate 4 in a pure form may be related to the weaker $\mathrm{Mn}-\mathrm{CF}_{2} \mathrm{CH}_{3}$ bond. All alkyl compounds were obtained by thermal decarbonylation of the corresponding acyl derivatives. However, while compounds $\mathbf{1}$, $\mathbf{2}$, and $\mathbf{3}$ are sufficiently robust and do not decompose during the decarbonylation step, compound 4 is more fragile. However, acyl derivative 5 is a suitable precursor for the generation of 4 , and, thus, of $\mathrm{CH}_{3} \mathrm{CF}_{2} \bullet$ radicals in situ. Preliminary polymerization tests have confirmed that the $\mathrm{Mn}-\mathrm{CF}_{3}$ complex (1) is able to initiate the VDF polymerization under both thermal and photochemical (visible, UV) conditions [23]. This article illustrates in fuller details the ability of complexes 1, 2, 3, and 5 to initiate and attempt controlling the polymerization of VDF and other monomers under thermal and photochemical conditions.

\section{Materials and Methods}

\subsection{Materials}

Vinylidene fluoride (VDF) and tert-butyl 2-(trifluoromethyl)acrylate (MAF-TBE) were kindly supplied by Arkema and Tosoh Finechem Corp., respectively, and used as received. Complexes 1, 2, 3, $\mathbf{5}$, and $\mathbf{6}$ were synthesized as described in a previous contribution [23]. Dimethyl carbonate (DMC, 
299\%, Merck KGaA), acetone (VMR Chemicals), pentane (VMR Chemicals), dimethyl formamide (VMR Chemicals), benzene- $d_{6}\left(99.5 \% \mathrm{D}\right.$, Eurisotop), acetone- $d_{6}\left(99.5 \% \mathrm{D}\right.$, Eurisotop), DMSO- $d_{6}(99.5 \% \mathrm{D}$, Eurisotop) and DMF- $d_{7}(99.5 \% \mathrm{D}$, Eurisotop) were used as received.

\subsection{Instrumentation}

The Nuclear Magnetic Resonance (NMR) spectra were recorded on a Bruker Avance III HD $400 \mathrm{MHz}$ spectrometer. The instrumental parameters were as follows. ${ }^{1} \mathrm{H}$ NMR: flip angle $=30^{\circ}$, acquisition time $=5.7 \mathrm{~s}$, pulse delay $=2 \mathrm{~s}$, number of scans $=64$, pulse width $=3.05 \mu \mathrm{s} .{ }^{19} \mathrm{~F}$ NMR: flip angle $=30^{\circ}$, acquisition time $=2 \mathrm{~s}$, pulse delay $=2 \mathrm{~s}$, number of scans $=64$, and pulse width $=3.76$ $\mu \mathrm{s}$. The probe has lower background ${ }^{19} \mathrm{~F}$ signals compared to standard dual-channel probes. SizeExclusion Chromatography (SEC) with $0.1 \mathrm{M} \mathrm{LiBr/DMF}$ as the eluent, calibrated with poly(methyl methacrylate) (PMMA) standards from Polymer Laboratories, was run with a Varian Prostar (model 210) pump at a flow rate of $0.8 \mathrm{~mL} \cdot \mathrm{min}^{-1}$ using two 300-mm long, mixed-D PL-gel and 5- $\mu \mathrm{m}$ columns (molar mass range: $2 \cdot 10^{2}-4 \cdot 10^{5} \mathrm{~g} \cdot \mathrm{mol}^{-1}$ from Polymer Laboratories) thermo-stated at $70^{\circ} \mathrm{C}$, connected to a Shodex (model RI-101) refractometer detector. The sample concentration was ca. $10 \mathrm{mg} \cdot \mathrm{mL}^{-1}$. The thermogravimetric analyses (TGA) of the purified and dried (co)polymer samples were performed in air using a TGA 51 apparatus from TA Instruments at a heating rate of $10^{\circ} \mathrm{C} \mathrm{min}^{-1}$ from room temperature to $580^{\circ} \mathrm{C}$. Differential scanning calorimetry (DSC) analyses of these samples were carried out using a Netzsch DSC 200 F3 instrument under an $\mathrm{N}_{2}$ atmosphere. The DSC instrument was calibrated with noble metals and checked before analysis with an indium sample $\left(T_{m}=156.6^{\circ} \mathrm{C}\right)$. After its insertion into the DSC apparatus, the sample was initially stabilized at $20^{\circ} \mathrm{C}$ for $10 \mathrm{~min}$. Then, the first scan was made at a heating rate of $10^{\circ} \mathrm{C} \cdot \mathrm{min}^{-1}$ up to $200^{\circ} \mathrm{C}$. It was then cooled to $-50{ }^{\circ} \mathrm{C}$. Lastly, a second scan was performed at a heating rate of $10^{\circ} \mathrm{C} \cdot \mathrm{min}^{-1}$ up to $200^{\circ} \mathrm{C}$. Melting points $\left(T_{m} \mathrm{~s}\right)$ were evaluated from the second heating, taken at the maximum of the enthalpy peaks, and its area determined the melting enthalpy $\left(\Delta H_{m}\right)$. This ensured the elimination of the thermal history of PVDFs during the first heating. The degrees of crystallinity of PVDFs were determined using Equation (1).

$$
\text { Degree of crystallinity }(\chi)=\left(\Delta H_{m} / \Delta H_{c}\right) \times 100
$$

where $\Delta H_{c}\left(104.5 \mathrm{~J} \mathrm{~g}^{-1}\right)$ corresponds to the enthalpy of melting of a $100 \%$ crystalline PVDF [24] while $\Delta H_{m}$ is the heat of fusion (determined by DSC in $\mathrm{J} \mathrm{g}^{-1}$ ), respectively.

\subsection{VDF Polymerizations with $\left[\mathrm{Mn}\left(\mathrm{R}_{\mathrm{F}}\right)(\mathrm{CO})_{5}\right]$}

The radical polymerizations of VDF were carried out in thick-walled $12 \mathrm{~mL}$ Carius tubes. As a representative example, a solution of $\left[\mathrm{Mn}\left(\mathrm{CF}_{3}\right)(\mathrm{CO})_{5}\right](128 \mathrm{mg}, 0.48 \mathrm{mmol})$ in $5 \mathrm{~mL}$ of dimethyl carbonate was introduced and degassed by three freeze-pump-thaw cycles. Then, the tube was cooled to the liquid nitrogen temperature and gaseous VDF monomer ( $1.5 \mathrm{~g}, 23.4 \mathrm{mmol})$ was transferred using a custom-made manifold that enables the accurate measurement of the gas quantity (using a "pressure drop vs. mass of monomer" calibration curve). The tube was then sealed under static vacuum at the liquid nitrogen temperature. For the thermal activation experiments, the tubes were placed horizontally in a thermostatic shaking water bath. For the visible light activation experiments, the tubes were placed horizontally in a tube roller shaker with 3 LED bulbs (Diall 1102270698, 14 W, $1521 \mathrm{Lm}$ ), irradiated from above, and placed $2 \mathrm{~cm}$ from the tubes. The proximity of the bulbs caused the tubes to warm up to $40^{\circ} \mathrm{C}$. For the UV activation experiments, the tubes were equipped with a small magnetic stirring bar and the solutions were stirred vertically in a Rayonet RPR-200 UV reactor equipped with sixteen 300-nm wavelength UV-lamps of $35 \mathrm{~W}$ each. Despite the fan placed inside the UV chamber, the heat generated by the UV lamps caused the tubes to warm up to $50^{\circ} \mathrm{C}$. After a certain time (ranging from 2 to $24 \mathrm{~h}$ ), each tube was frozen into liquid nitrogen, opened, and the solvent was evaporated in a rotary evaporator. The monomer conversion was calculated from the PVDF yields (Equation (2), where $\mathrm{m}_{\mathrm{PVDF}}, \mathrm{m}_{\mathrm{VDF}}$, and $\mathrm{m}_{\text {complex }}$ stand for the recovered mass of PVDF, the initial 
mass of VDF, which was obtained from the pressure measurement, and the mass of complex $\mathbf{1}$ used to initiate the polymerization, respectively) since an accurate direct measurement of the VDF conversion is complicated by the gaseous state of the monomer.

$$
\text { Conversion }(\%)=1-\left[\mathrm{m}_{\mathrm{PVDF}} /\left(\mathrm{m}_{\mathrm{VDF}}+\mathrm{m}_{\text {complex }}\right)\right] \times 100
$$

The resulting polymers were dissolved in DMF- $d_{7}$, DMSO- $d_{6}$, or acetone- $d_{6}$ (depending on the solubility) and characterized by ${ }^{1} \mathrm{H}$ and ${ }^{19} \mathrm{~F}$ NMR spectroscopy. Molar masses and dispersities were determined by SEC in DMF (refractive index, calibrated with PMMA standards).

\subsection{Copolymerization of VAc and MAF-TBE}

The radical co-polymerizations of VAc and MAF-TBE were carried out in a Schlenk tube under an argon atmosphere. As a representative example, $93.3 \mathrm{mg}$ of $\left[\mathrm{Mn}(\mathrm{CO})_{5}\left(\mathrm{CH}_{2} \mathrm{CF}_{3}\right)\right]\left(3.35 \cdot 10^{-1} \mathrm{mmol}\right)$ were introduced in a Schlenk tube. Then, $1.554 \mathrm{~g}$ of VAc $(18.1 \mathrm{mmol})$ and $3.324 \mathrm{~g}$ of MAF-TBE $(16.9 \mathrm{mmol})$ were added. The resulting solution was degassed by three freeze-pump-thaw cycles, and placed under argon. The solution was heated up to $80^{\circ} \mathrm{C}$ for $18 \mathrm{~h}$, and the resulting dark yellow solid was dissolved in $15 \mathrm{~mL}$ of acetone. The polymer was precipitated by adding the solution dropwise to $200 \mathrm{~mL}$ of cold $n$-pentane and then the precipitate was dried at $80^{\circ} \mathrm{C}$ under vacuum for $16 \mathrm{~h}$, which yielded $4.053 \mathrm{~g}$ of a yellow-brownish solid (83\% yield). The polymer was dissolved in acetone- $d_{6}$ and analyzed by ${ }^{1} \mathrm{H}$ and ${ }^{19} \mathrm{~F}$ NMR spectroscopies. The molar masses and dispersities were determined by SEC in DMF (refractive index, calibrated with PMMA standards).

\section{Results}

\subsection{Radical Polymerization of VDF with $\mathbf{1}$ as an Initiator}

Several polymerizations of VDF using complex $\mathbf{1}$ as the initiator were carried out under thermal and photochemical conditions (Scheme 1). Among all the fluoroalkylpentacarbonylmanganese(I) complexes synthesized in previous contributions [23,25], compound $\mathbf{1}$ possesses the strongest $\mathrm{Mn}-\mathrm{C}$ $\mathrm{BDE}$, according to the computational and experimental investigations data. Therefore, it is necessary to apply a relatively high temperature to cleave the $\mathrm{Mn}-\mathrm{CF}_{3}$ bond. In the case of thermal activation, the experiment was run at $100^{\circ} \mathrm{C}$, which is a temperature at which the determined half-life in $\mathrm{C}_{6} \mathrm{D}_{6}$ is 37.2 minutes and considers that $99 \%$ of the complex decomposes ( $\left.\mathrm{t}_{99 \%}\right)$ after $4.1 \mathrm{~h}$ [23]. Once the $\mathrm{F}_{3} \mathrm{C}^{\bullet}$ radicals have been generated, their addition to a monomer should be fast. The photochemical initiation was carried out either by visible light irradiation using LED bulbs or by UV irradiation using a monochromatic $300 \mathrm{~nm}$ lamp.
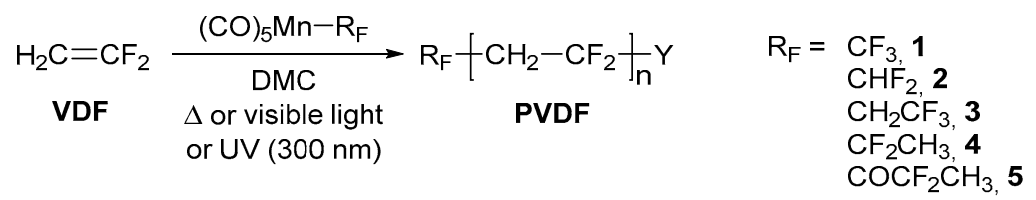

Scheme 1. General synthetic pathway employed to synthesize PVDF using fluoroalkylpentacarbonylmanganese(I) complexes as initiators under thermal or photochemical conditions. Y stands for $\mathrm{Mn}(\mathrm{CO})_{5}$ or $\mathrm{H}$ or $\mathrm{R}_{\mathrm{F}}$.

Control experiments for both thermal and photochemical (visible light) activations carried out in the presence of $\left[\mathrm{Mn}_{2}(\mathrm{CO})_{10}\right]$ instead of $\mathbf{1}$ did not yield to any PVDF. Since $\left[\mathrm{Mn}_{2}(\mathrm{CO})_{10}\right]$ is known to generate $\left[(\mathrm{CO})_{5} \mathrm{Mn}^{\bullet}\right]$ radicals under both thermal and photochemical conditions [26], it can be concluded that $\left[(\mathrm{CO})_{5} \mathrm{Mn}^{\bullet}\right]$ is not capable of adding to VDF to initiate the polymerization. This result confirms previous studies reported by Bamford et al. [27] and by Asandei et al. [13], which showed that $\left[(\mathrm{CO})_{5} \mathrm{Mn}^{\bullet}\right]$ photoproduced from $\left[\mathrm{Mn}_{2}(\mathrm{CO})_{10}\right]$ is unable to initiate the radical polymerization of VDF (although it does initiate those of $\mathrm{C}_{2} \mathrm{~F}_{4}$ and $\mathrm{C}_{2} \mathrm{~F}_{3} \mathrm{Cl}$ ) [27]. 
Several polymerizations were carried out with complex $\mathbf{1}$ as an initiator under thermal and photochemical activations, which stopped the reactions at different times. The reaction conditions and analytical data of the resulting polymers are summarized in Table 1. All reactions were performed targeting a degree of polymerization of 50, expecting a molar mass of ca. $3500 \mathrm{~g} \cdot \mathrm{mol}^{-1}$ under the assumption of a well-controlled OMRP [28] with the pentacarbonylmanganese radical as a moderating agent.

Table 1. Results for the VDF polymerization initiated by the thermal or photochemical activations of $\mathbf{1}$.

\begin{tabular}{|c|c|c|c|c|c|}
\hline Entry & Activation Method & Reaction Time (h) & Yield a (\%) & $M_{n}^{b}\left(g \cdot \mathrm{mol}^{-1}\right)$ & Đ \\
\hline 1 & Thermal $\left(50^{\circ} \mathrm{C}\right)$ & 24 & 0 & - & - \\
\hline 2 & Thermal $\left(100^{\circ} \mathrm{C}\right)$ & 2 & 6 & 16,000 & 1.42 \\
\hline 3 & Thermal $\left(100^{\circ} \mathrm{C}\right)$ & 4 & 15 & 23,000 & 1.48 \\
\hline 4 & Thermal $\left(100^{\circ} \mathrm{C}\right)$ & 6 & 38 & 20,100 & 1.50 \\
\hline 5 & Thermal $\left(100^{\circ} \mathrm{C}\right)$ & 12 & 40 & ND & ND \\
\hline 6 & Thermal $\left(100^{\circ} \mathrm{C}\right)$ & 18 & 49 & ND & ND \\
\hline 7 & Thermal $\left(100^{\circ} \mathrm{C}\right)$ & 24 & 68 & 16,900 & 1.53 \\
\hline 8 & Visible light & 2 & 6 & ND & ND \\
\hline 9 & Visible light & 4 & 14 & 53,000 & 1.65 \\
\hline 10 & Visible light & 6 & 19 & 48,300 & 1.61 \\
\hline 11 & Visible light & 24 & 60 & 40,300 & 1.47 \\
\hline 12 & UV (300 nm) & 2 & 9 & 11,000 & 1.84 \\
\hline 13 & UV (300 nm) & 6 & 18 & 19,200 & 1.76 \\
\hline 14 & UV (300 nm) & 24 & 74 & 26,000 & 1.63 \\
\hline
\end{tabular}

a Determined from the mass of the isolated polymer. ${ }^{b}$ Calculated by SEC in DMF with refractive index detection (calibrated with PMMA standards). ND = not determined. Experimental conditions: $128 \mathrm{mg}$ of $\left[\mathrm{Mn}\left(\mathrm{CF}_{3}\right)(\mathrm{CO})_{5}\right]$, $1.5 \mathrm{~g}$ of VDF, and $5 \mathrm{~mL}$ of DMC in glass Carius tubes.

A first thermal VDF polymerization test (with protection from light) was performed at $50{ }^{\circ} \mathrm{C}$ for $24 \mathrm{~h}$ (entry 1). Such conditions did not lead to the formation of any PVDF, which means that this temperature is too low to homolytically cleave the $\mathrm{Mn}-\mathrm{CF}_{3}$ bond in $\mathbf{1}$. Extrapolation of the previously determined activation parameters to $50^{\circ} \mathrm{C}$ leads to a half-life of $9 \times 10^{8} \mathrm{~s}$ (ca. 29 years) for compound 1 at this temperature [23]. However, PVDF was produced in high yields (up to $70 \%$ after $24 \mathrm{~h}$ ) at higher temperature $\left(100^{\circ} \mathrm{C}\right.$, entries 2 to 7$)$. As mentioned above, $100^{\circ} \mathrm{C}$ leads to a relatively rapid generation of $\mathrm{F}_{3} \mathrm{C}^{\bullet}$ radicals from 1 in $\mathrm{C}_{6} \mathrm{D}_{6}\left(\mathrm{t}_{\frac{1}{2}} \approx 37 \mathrm{~min}, \mathrm{t}_{99} \% 4 \mathrm{~h}\right)$ [23]. Hence, new polymer chains should be generated $4 \mathrm{~h}$ after the beginning of the polymerization assuming a similar $\mathrm{t}_{1 / 2}$ in DMC/VDF to that determined in $\mathrm{C}_{6} \mathrm{D}_{6}$.

The most interesting result concerning the thermal activation is that the polymer yield keeps increasing beyond $4 \mathrm{~h}$ of reaction and even after $18 \mathrm{~h}$ (e.g., from $49 \%$ after $18 \mathrm{~h}$, entry 6 , to $68 \%$ after $24 \mathrm{~h}$, entry 7). This result indicates either the intervention of a reversible $\mathrm{PVDF}^{\bullet}$ trapping by $\left[\mathrm{Mn}(\mathrm{CO})_{5}{ }^{\bullet}\right]$ (i.e. an OMRP mechanism) or a much longer initiator half-life in the DMC/VDF medium relative to $\mathrm{C}_{6} \mathrm{D}_{6}$. The dispersities of the recovered polymers continuously increased as a function of conversion, which is consistent with a relatively slow initiator decomposition, whereas the molar masses initially increased, and then decreased (entries 3-7). These characteristics indicate poor control, although the presence of some degree of OMRP trapping cannot be excluded.

The polymerization initiation was also very effective under photochemical conditions. Initiation by visible light led to PVDF in high yields (60\% after $24 \mathrm{~h}$, entry 11$)$, as well as by UV irradiation (74\% after $24 \mathrm{~h}$, entry 14). It is worth noting that the measured reaction temperature, self-regulated by heat released by the LED bulbs, was $40{ }^{\circ} \mathrm{C}$ during the experiment, and $50^{\circ} \mathrm{C}$ in the UV reactor. However, entry 1 proves that this temperature is not sufficient to release radicals. Thus, it is confirmed that visible light and $\mathrm{UV}$ irradiation lead to $\mathrm{Mn}-\mathrm{CF}_{3}$ bond cleavage to produce $\mathrm{F}_{3} \mathrm{C}^{\bullet}$ radicals. For these experiments, a tendency for a slight decrease of the polymer dispersities as a function of conversion was observed. However, visible light activation, contrary to the UV one, induces a decrease of the molar masses with conversion. Their values are much greater than expected based on a controlled 
polymerization. This may be caused by a lower initiation efficiency or slower $\mathrm{Mn}-\mathrm{CF}_{3}$ homolytic cleavage under visible irradiation than under $\mathrm{UV}$ or at $100^{\circ} \mathrm{C}$. Thus, it appears that generation of the $\left\{\left[\mathrm{Mn}(\mathrm{CO})_{5}{ }^{\bullet}\right], \mathrm{PVDF}^{\bullet}\right\}$ radical pair is not followed by efficient trapping to produce an organometallic dormant species. Rather, radicals escape from the solvent cage and subsequent uncontrolled chain growth and termination processes predominantly occur.

The polymerization kinetics are close to first-order and confirm that the polymerization proceeds with an approximately constant radical concentration (Figure 1, Figure S1 and Figure S2).

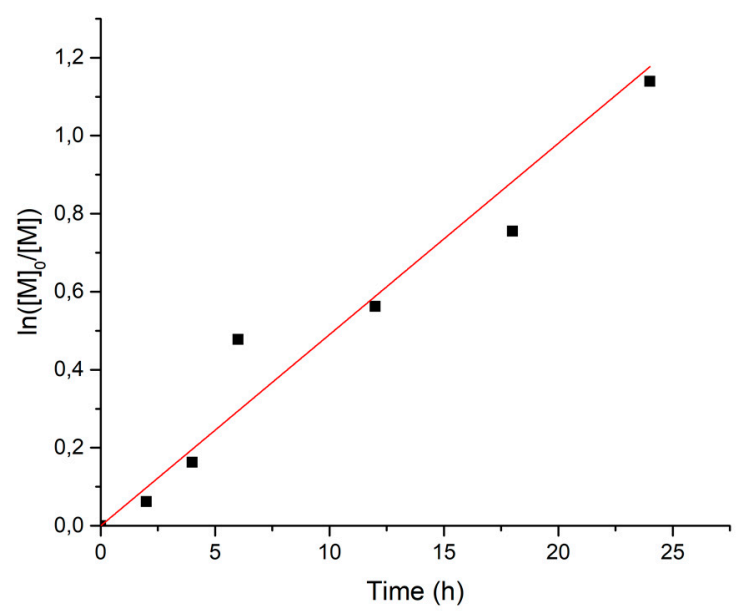

Figure 1. First-order kinetics plot for the polymerization of VDF in the presence of $\left[\mathrm{Mn}\left(\mathrm{CF}_{3}\right)(\mathrm{CO})_{5}\right]$ initiated thermally $\left(100^{\circ} \mathrm{C}\right)$.

The size exclusion chromatograms of PVDF samples obtained by thermal activation (Figure S3) exhibit two different populations: the main one displays a significant molar mass increase at the beginning (entries 2-3) and then a decrease (entries 3-7), which proves the lack of control during the reaction. The negative signal in the size exclusion chromatograms results from the lower refractive index of PVDF relative to the DMF eluent $[5,29,30]$. The signal of the second population at low molar mass can be attributed to oligomers arising from transfer reactions. Thus, the behavior of this polymerization is a conventional radical polymerization. This is also confirmed by an increase of the dispersity accompanied by a decrease of the average molar masses (Figure S7), as frequently observed in conventional radical polymerization. This behavior is also likely caused by hydrogen atom transfer from DMC, which stops the growing macroradicals to yield dead PVDF chains and generates new radicals that can create new chains initiated by the $\mathrm{H}_{3} \mathrm{COC}(\mathrm{O}) \mathrm{OCH}_{2}{ }^{\bullet}$ radical. However, despite the lack of control, a high conversion (68\%) was reached after $24 \mathrm{~h}$, which establishes complex $\mathbf{1}$ as an efficient initiator of VDF polymerization.

The size exclusion chromatograms in Figure S4 show the PVDF mass evolution during the visible light initiation. As above, the average molar mass decreases (compare entries 9 and 13). The plots of molar masses and dispersities versus conversion of the polymerization carried out under visible light activation (entries 9, 10, and 11, Table 1) are represented in Figure S8. Molar masses decrease with conversion such as in a conventional radical polymerization. Surprisingly, it should be noted that the dispersity slightly decreases with time.

The SEC traces of the crude polymers obtained by UV irradiation are represented in Figure S5. The evolution of the number of average molar masses and dispersities versus VDF conversion (Figure 2) clearly shows an increase of the molar mass and a decrease of dispersity during the polymerization. Both parameters evolve significantly at the beginning of the polymerization. This evolution seems less pronounced at the end of the reaction. In addition, the initially present low molar mass population gradually disappears. The observed trends in this polymerization are suggestive of a certain level control for an RDRP. However, the final polymer dispersity was relatively high $(Ð=1.63)$ while 
the $\mathrm{M}_{\mathrm{n}}\left(26,000 \mathrm{~g} \cdot \mathrm{mol}^{-1}\right)$ was much lower than that obtained from the visible light activation, and significantly higher than that observed with thermal initiation (Figure S6). In addition, the $M_{n}$ growth and the dispersity drop were not linear, which suggests a certain control mainly at the beginning of the polymerization.

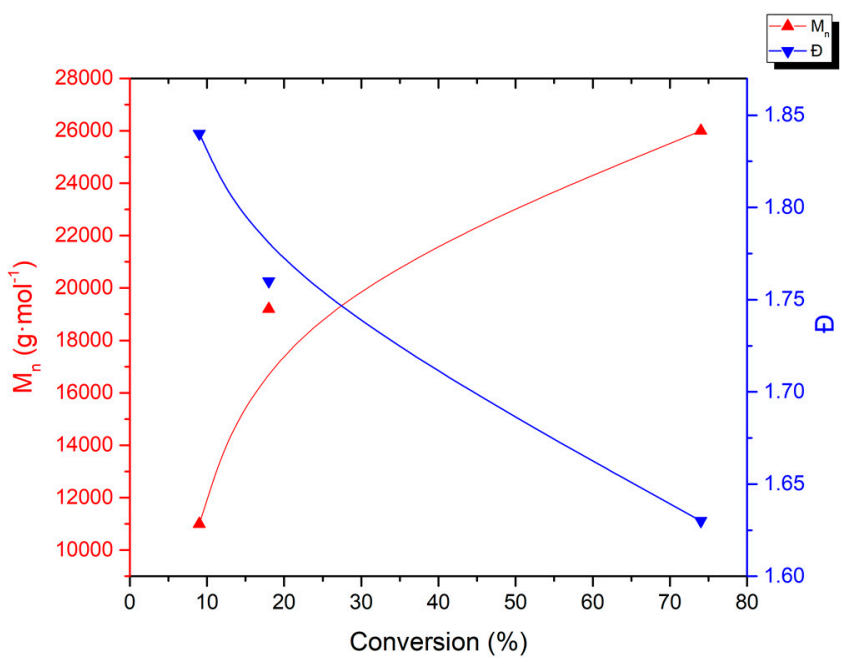

Figure 2. Plots of the number of average molar masses and dispersities vs. conversion of VDF polymerization initiated by UV irradiation in the presence of $\left[\mathrm{Mn}\left(\mathrm{CF}_{3}\right)(\mathrm{CO})_{5}\right]$.

\subsection{NMR Characterization of PVDFs}

The ${ }^{1} \mathrm{H}$ NMR spectra of the recovered polymers after $24 \mathrm{~h}$ for the three different initiation methods (Figure 3, Figure S9, Figure S11 and Figure S13) exhibit the characteristic PVDF signals centered at 2.4 (minor) and 3.0 (major) ppm, assigned to the reverse $-\mathrm{CF}_{2} \mathrm{CH}_{2}-\mathrm{CH}_{2} \mathrm{CF}_{2}$ - (tail-to-tail) and regular $-\mathrm{CH}_{2} \mathrm{CF}_{2}-\mathrm{CH}_{2} \mathrm{CF}_{2}-$ monomer additions, respectively $[3,6,13,31,32]$. The triplet $\left({ }^{2} J_{\mathrm{HF}}=55 \mathrm{~Hz}\right)$ of triplets $\left({ }^{3} J_{\mathrm{HH}}=7 \mathrm{~Hz}\right)$ at $\delta 6.44 \mathrm{ppm}$ is attributed to the proton in the $-\mathrm{CH}_{2}-\mathrm{CF}_{2} \mathrm{H}$ chain-ends generated by hydrogen transfer from the solvent, or by backbiting, which both involve the main $\left(-\mathrm{CH}_{2}-\mathrm{CF}_{2}{ }^{\bullet}\right)$ macroradical [33]. Similarly, this hydrogen transfer to the minor $-\mathrm{CF}_{2}-\mathrm{CH}_{2} \bullet$ macroradical is responsible for the observed triplet $\left({ }^{3} J_{\mathrm{HF}}=18 \mathrm{~Hz}\right)$ centered at $\delta 1.85 \mathrm{ppm}$, which is assigned to the methyl end-group in $-\mathrm{CF}_{2}-\mathrm{CH}_{3}[6,13,31]$. From the relative signal integrals, it seems that the hydrogen transfer rates are lower for the polymerization carried out under visible light and UV light activation compared to the thermal initiation, according to the different measured molar masses (entries 11, 14, and 7 in Table $1, \mathrm{M}_{\mathrm{n}}=40300,26,000$, and $16,900 \mathrm{~g} \cdot \mathrm{mol}^{-1}$, respectively). The transfer side-reaction leads to a decrease of the number of average molar mass and to an increase of dispersity, as observed in entries 3-7. In addition, two relatively intense resonances at $\delta 4.38$ and $3.79 \mathrm{ppm}$ in an approximate 2:3 ratio may be assigned to the $-\mathrm{CF}_{2}-\mathrm{CH}_{2}-\mathrm{CH}_{2}-\mathrm{OC}(\mathrm{O}) \mathrm{O}-\mathrm{CH}_{3}$ chain ends, which results from a chain transfer to the DMC solvent [14] because their integrated intensities are consistent with that of the $\mathrm{CH}_{2} \mathrm{CF}_{2} \mathrm{H}$ signal. This is simultaneously generated by the same process $(1: 2: 3$ for the $\delta 6.44,4.38$, and $3.79 \mathrm{ppm}$ resonances, respectively) [6,14]. 


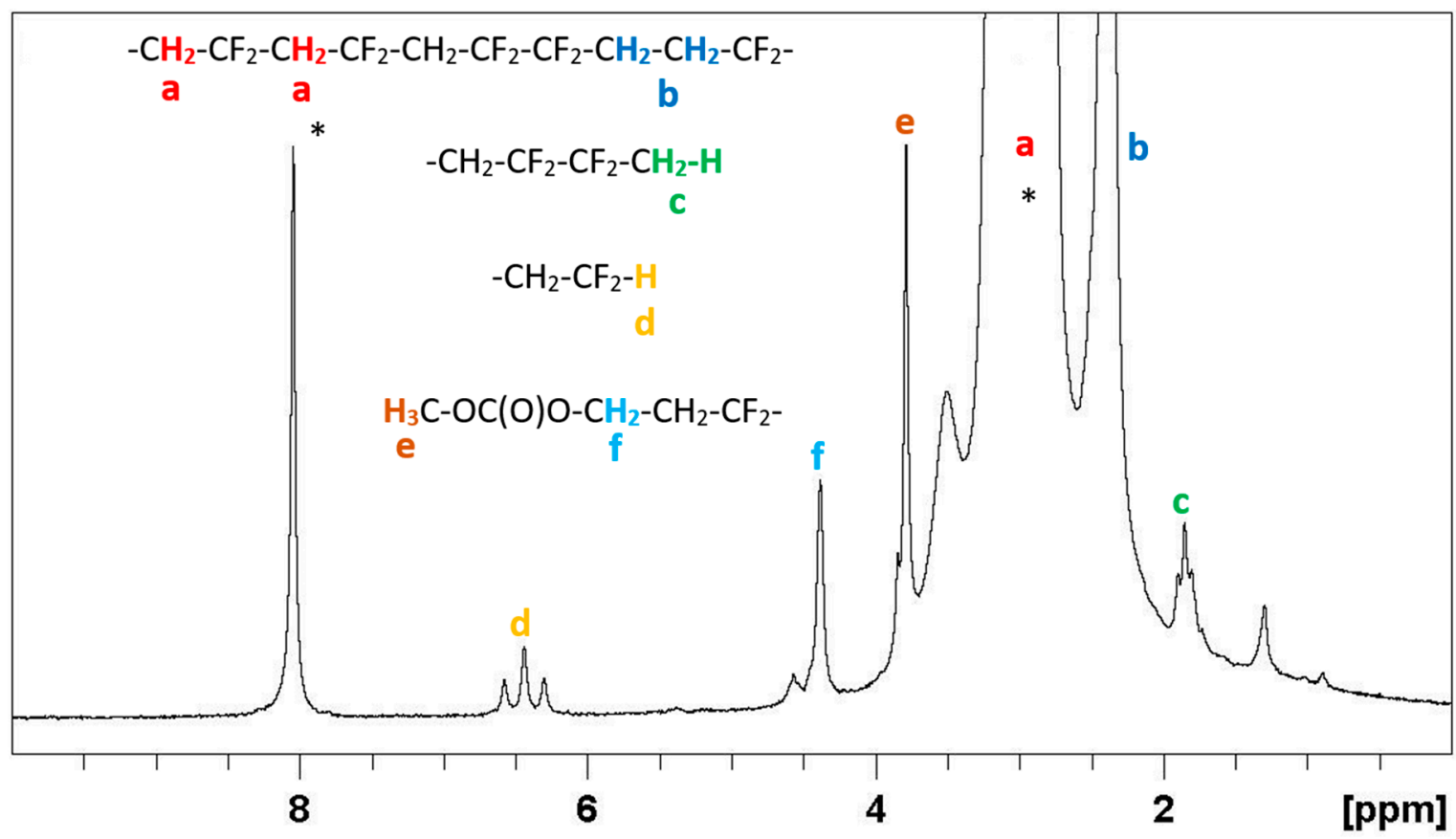

Figure 3. ${ }^{1} \mathrm{H}$ NMR spectrum $\left(400 \mathrm{MHz}, \mathrm{DMF}-d_{7}\right)$ between 0 and $10 \mathrm{ppm}$ of the PVDF obtained by thermal activation of $\mathbf{1}$ (entry 7 of Table 1). The full spectrum is shown in the SI (Figure S9). The starred resonances are due to the solvent.

The ${ }^{19} \mathrm{~F}$ NMR spectra of the PVDF obtained from the three activation methods (Figures S10, S12, and S14) also exhibit all the expected resonances of PVDF $[6,13,14,31,32,34,35]$. The characteristic signal centered at $-91.9 \mathrm{ppm}$ (a in Figure 4 ) is assigned to the regular $-\mathrm{CH}_{2} \mathrm{CF}_{2}-\mathrm{CH}_{2} \mathrm{CF}_{2}$ - (head-to-tail, $\mathrm{H}-\mathrm{T}$ ) sequences. The head-to-head $\left(\mathrm{H}-\mathrm{H},-\mathrm{CH}_{2} \mathrm{CF}_{2}-\mathrm{CF}_{2} \mathrm{CH}_{2}-\right)$ sequences, which are systematically followed by tail-to-tail (T-T, $-\mathrm{CF}_{2} \mathrm{CH}_{2}-\mathrm{CH}_{2} \mathrm{CF}_{2}$ ) sequences, give rise to the resonances at -113.9 and -116.2 ppm ( $\mathbf{c}$ and $\mathbf{d}$, respectively). The percentage of $\mathrm{H}-\mathrm{H}$ additions, obtained from the integrals of the ${ }^{19} \mathrm{~F}$ NMR signals (for the 24-hour-reaction, the fractions are 3.9\%, 3.5\% and 3.9\% for the thermal, visible light and UV initiations, respectively) is typical for a PVDF produced by radical polymerization [36]. The $\mathrm{F}_{3} \mathrm{C}^{\bullet}$ radicals generated from 1 should preferentially attack the VDF tail $\left(\mathrm{CH}_{2}\right)$, as described in previous studies [32,34,37-39]. The head-end attack was reported to occur at less than $3 \%$ frequency at $150{ }^{\circ} \mathrm{C}$ [37]. Thus, the use of this radical should not significantly affect the percentage of inverted monomer additions. The $\mathrm{CF}_{3}-\mathrm{CH}_{2}-\mathrm{CF}_{2}$ - chain-end produced by the initiation of the $\mathrm{F}_{3} \mathrm{C}^{\bullet}$ radical could be shown by a small signal at $\delta-60.8 \mathrm{ppm}$, which confirms the previous studies $[32,34,39]$, but only for the PVDF obtained by UV activation despite the high molar mass of the polymer. On the other hand, the expected signals for the chain ends generated by the transfer processes are always visible, as displayed in the spectra ( $\mathbf{g}$ and $\mathbf{h}$ in Figure 4 and Figure S14, $\mathbf{h}$ and $\mathbf{i}$ in Figure S12). In addition, several unidentified small signals are present at $\delta-150.0,-99.0,-98.3$, and $-85.0 \mathrm{ppm}$ in the case of the thermal activation, and an even smaller one at $\delta-85.0 \mathrm{ppm}$ for the UV activation, which suggests that side-reactions occurred during the VDF polymerization carried out under these conditions. These signals were not observed for the polymers obtained by visible light initiation. It is important to underline that the ${ }^{19} \mathrm{~F}$ NMR resonance of 1 (expected at $\delta 5.65 \mathrm{ppm}$ ) [23] was not observed in any of the isolated PVDF products, which indicates full consumption of this compound. 


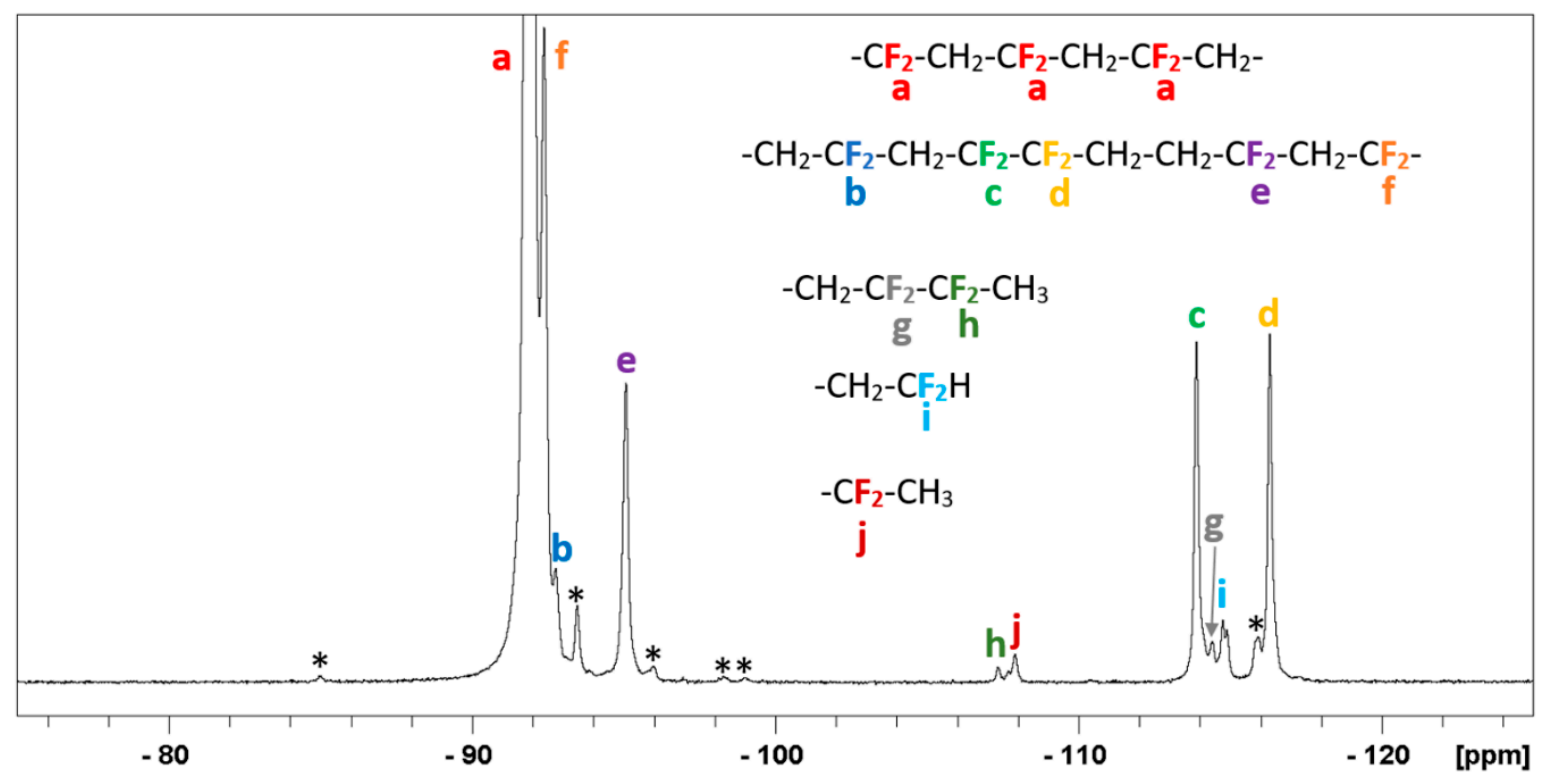

Figure 4. ${ }^{19} \mathrm{~F}$ NMR spectrum $\left(376.5 \mathrm{MHz}, \mathrm{DMF}-d_{7}\right)$ between -75 and $-125 \mathrm{ppm}$ of the PVDF obtained by thermal activation of $\mathbf{1}$ (entry 5 in Table 1). The full spectrum is shown in Figure S10. The starred resonances could not be attributed to any expected signal of possible products.

\subsection{Thermal Properties of the Resulting PVDFs}

The thermal properties of the PVDF samples obtained by thermal or photochemical activations of compound 1 after a 24 h-reaction was studied by thermogravimetric analysis (TGA) and differential scanning calorimetry (DSC). Figure 5 displays the TGA thermograms of three PVDFs achieved from various initiations while Table 2 summarizes the temperatures at which $2 \%, 5 \%$, and $10 \%$ weight losses are noted.

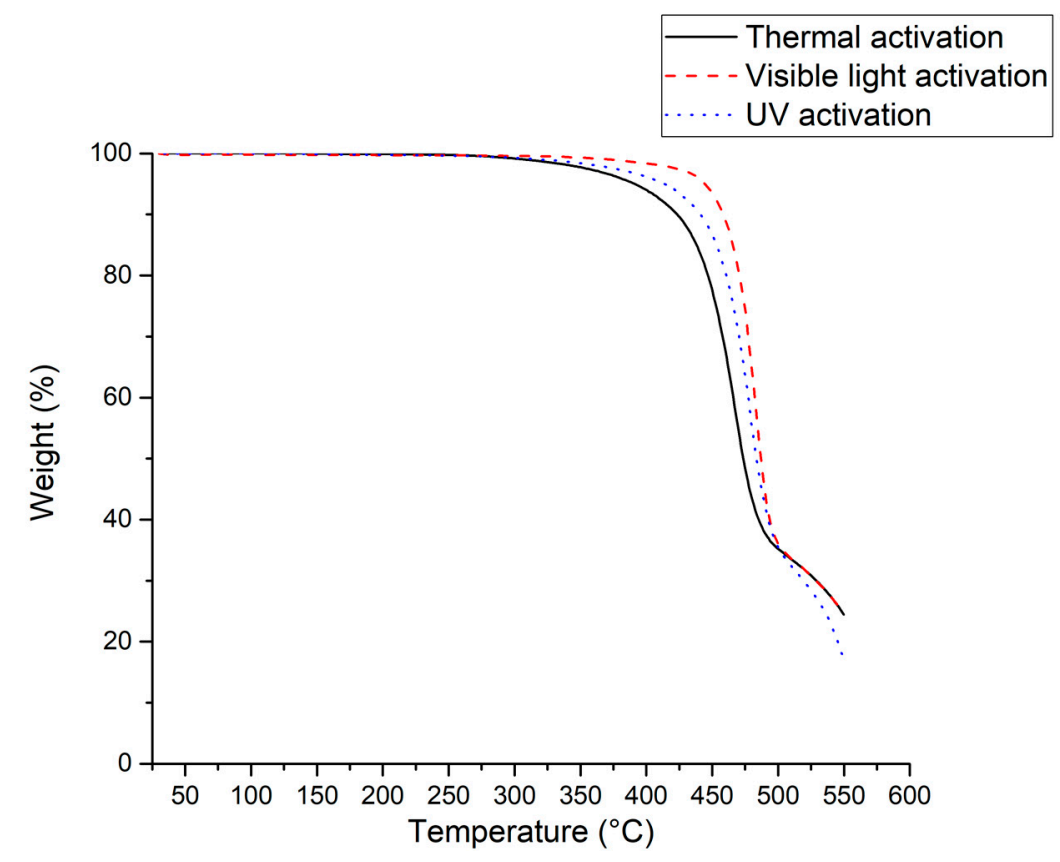

Figure 5. TGA thermograms in the air of PVDFs obtained by polymerization of VDF in the presence of $\left[\mathrm{Mn}\left(\mathrm{CF}_{3}\right)(\mathrm{CO})_{5}\right]$ after a 24 h-reaction and initiated thermally (full line), by visible (dashed line) or UV (dotted line) light. 
Table 2. Temperatures of decomposition (in air) of PVDFs synthesized with $\left[\mathrm{Mn}\left(\mathrm{CF}_{3}\right)(\mathrm{CO})_{5}\right]$ after a 24 h-reaction $(2 \%, 5 \%$, and $10 \%$ wt. loss).

\begin{tabular}{ccccc}
\hline Activation Method & $\mathbf{M}_{\mathbf{n}} \mathbf{( g \cdot \mathbf { m o l } ^ { - \mathbf { 1 } } )}$ & $\mathbf{T}_{\mathbf{2} \%}$ & $\mathbf{T}_{\mathbf{5} \%}$ & $\mathbf{T}_{\mathbf{1 0} \%}$ \\
\hline Thermal $\left(100{ }^{\circ} \mathrm{C}\right)$ & 16,900 & 343 & 391 & 424 \\
Visible light & 40,300 & 412 & 444 & 459 \\
UV (300 nm) & 26,000 & 364 & 414 & 441 \\
\hline
\end{tabular}

As shown in Table 2, the higher the molar mass of PVDF is, the higher its thermal stability is. The polymer synthesized under visible light, with the highest molar mass $\left(\mathrm{M}_{\mathrm{n}}=40,300 \mathrm{~g} \mathrm{~mol}^{-1}\right)$, exhibits a $2 \%$ weight loss at the highest temperature $\left(412{ }^{\circ} \mathrm{C}\right)$, whereas that obtained from thermal initiation, with the lowest molar mass $\left(\mathrm{M}_{\mathrm{n}}=16,900 \mathrm{~g} \mathrm{~mol}^{-1}\right)$ shows the same weight loss at the lowest temperature $\left(343^{\circ} \mathrm{C}\right)$.

On the other hand, as expected, all DSC thermograms of the synthesized PVDFs (Figure 6) did not exhibit any glass transition $\left(\mathrm{T}_{\mathrm{g}}\right.$ is expected at $\left.-40^{\circ} \mathrm{C}\right)[1,4]$. However, the thermograms revealed the crystalline phase melting at higher temperatures for the higher molar masses (reaching $175^{\circ} \mathrm{C}$, which is in good agreement with previous reports [4] for the PVDF obtained by visible light initiation; see Table 3). The highest molar mass polymer also showed the highest degree of crystallinity $(53 \%)$, whereas the lower molar mass polymers obtained by thermal or UV activations were less crystalline (44\%).

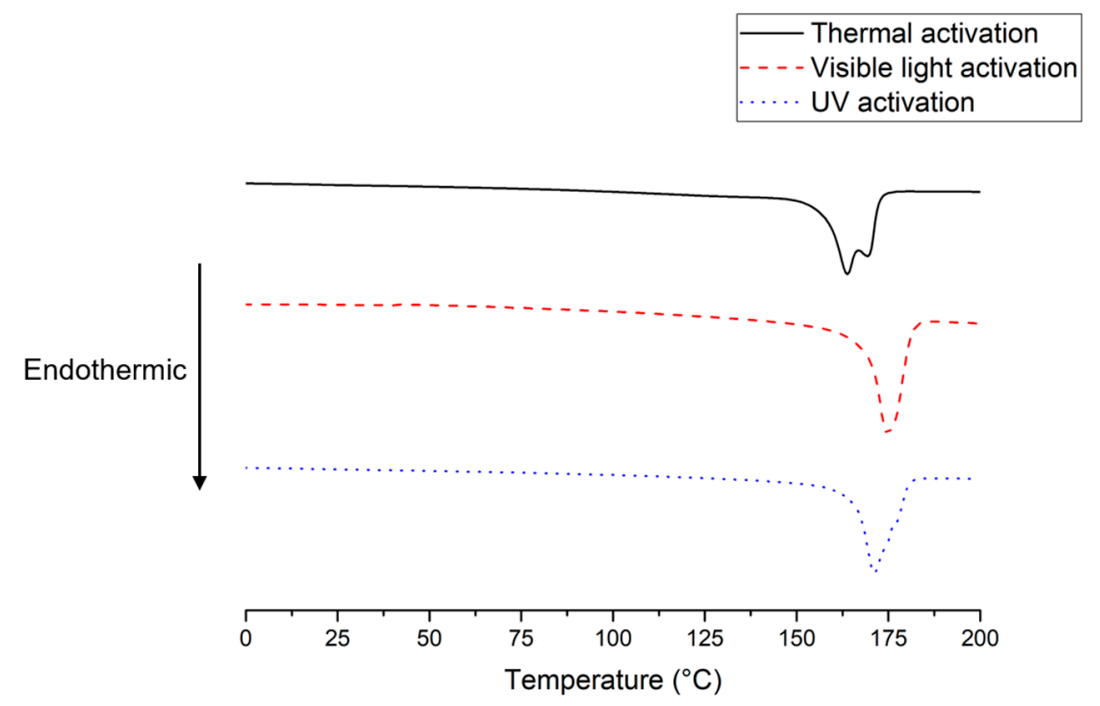

Figure 6. DSC thermograms of PVDFs synthesized in the presence of complex $\mathbf{1}$ after a 24 h-reaction with different activation methods.

Table 3. Molar masses and thermal characteristics of PVDFs obtained by polymerization of VDF in the presence of complex 1 from different activation methods.

\begin{tabular}{ccccc}
\hline $\begin{array}{c}\text { Activation } \\
\text { Method }\end{array}$ & $\begin{array}{c}\mathbf{M}_{\mathbf{n}} \\
\left(\mathbf{g} \cdot \mathbf{m o l}^{\mathbf{- 1}}\right)\end{array}$ & $\begin{array}{c}\text { Melting Point } \\
\left({ }^{\circ} \mathbf{C}\right)\end{array}$ & $\begin{array}{c}\text { Enthalpy of } \\
\text { Fusion }\left(\mathbf{J} \cdot \mathbf{g}^{-\mathbf{1}}\right)\end{array}$ & $\begin{array}{c}\text { Degree of } \\
\text { Crystallinity * (\%) }\end{array}$ \\
\hline Thermal $\left(100{ }^{\circ} \mathrm{C}\right)$ & 16,900 & 164 & 46.1 & 44 \\
Visible light & 40,300 & 175 & 55.3 & 53 \\
UV $(300 \mathrm{~nm})$ & 26,000 & 171 & 45.9 & 44 \\
\hline
\end{tabular}

* Assessed from Equation (1).

\subsection{Radical Polymerization of VDF with 2, 3, and $\mathbf{5}$ as Initiator}

Compound $\left[\mathrm{Mn}\left(\mathrm{CHF}_{2}\right)(\mathrm{CO})_{5}\right]$ (2) has a weaker Mn-C bond dissociation energy (BDE) than 1 and even weaker than $\left[\mathrm{Mn}\left(\mathrm{CH}_{2} \mathrm{CF}_{3}\right)(\mathrm{CO})_{5}\right](3)$, as confirmed by both the experimentally determined 
and the calculated BDEs [23]. Thus, the radical generation should require less energy compared to compound 1 . Therefore, $80^{\circ} \mathrm{C}$ was chosen as the reaction temperature to initiate the polymerization by the thermal activation mode ( $\mathrm{t}_{\frac{1}{2}} \approx 46 \mathrm{~min}$ and $\mathrm{t}_{99 \%} \approx 5 \mathrm{~h}$ for 2 at $80{ }^{\circ} \mathrm{C}_{\text {in }} \mathrm{C}_{6} \mathrm{D}_{6}$ ) [23]. This temperature was also selected for complex [Mn $\left.\left(\mathrm{COCF}_{2} \mathrm{CH}_{3}\right)(\mathrm{CO})_{5}\right]$ (5), which is expected [23] to undergo thermal decarbonylation and to form the alkyl complex $\left[\mathrm{Mn}\left(\mathrm{CF}_{2} \mathrm{CH}_{3}\right)(\mathrm{CO})_{5}\right](4)$ in-situ before generating $\mathrm{CH}_{3} \mathrm{CF}_{2}{ }^{\bullet}$ radicals. In the case of complex $3,90^{\circ} \mathrm{C}$ was chosen as the reaction temperature due to its slightly higher BDE compared to complex $2\left(\mathrm{t}_{\frac{1}{2}} \approx 21.6 \mathrm{~min}\right.$ and $\mathrm{t}_{99} \% 2.4 \mathrm{~h}$ at $90{ }^{\circ} \mathrm{C}$ in $\left.\mathrm{C}_{6} \mathrm{D}_{6}\right)$ [23]. The experimental conditions and the results are presented in Table 4.

The thermal activation of 2 at $80^{\circ} \mathrm{C}$ for $24 \mathrm{~h}$ (entry 1 in Table 4 ) led only to a small amount of a brown-yellowish powder. However, this material does not contain any PVDF, as shown by the absence of observable resonances in the ${ }^{19} \mathrm{~F}$ NMR spectrum. Photochemical initiation, on the other hand, led to PVDF formation, which is only in very low yields (entries 2 and 3 of Table 4). This is much lower than for compound 1 under the same conditions. Similar low yields were obtained by thermally initiating the polymerization with complex 3 (entries 4-6). Photoactivation experiments were not carried out with this complex. In this case, the polymers were analyzed by SEC and found to have high molar masses, which is essentially independent of the monomer/initiator ratio and of the activation temperature $\left(90\right.$ or $\left.100{ }^{\circ} \mathrm{C}\right)$, which are quite similar to those of the polymers obtained in much higher yields using 1 as the initiator. However, these polymers surprisingly show low dispersities likely because of the very small quantities of the polymer that could be injected in the SEC apparatus (the signal/noise ratios were very close to unity in these cases). The polymerizations initiated by complex 5 led to slightly greater polymer yields, but still much lower than those initiated by complex 1 . Thermal activation gave only a 7\% yield after $24 \mathrm{~h}$ (entry 7, Table 4), while visible light (entries 8-11) and UV light (entries 12-15) irradiation gave yields that increased with irradiation time up to $23 \%$ or $21 \%$, respectively, after $24 \mathrm{~h}$. The molar masses of these polymers, like those obtained from initiation with $\mathbf{1}$, are high and the dispersities are moderate. Once again, this suggests the absence of a controlled chain growth of the type expected from OMRP. Since we have established that the Mn- $\mathrm{R}_{\mathrm{F}}$ bond is homolytically weaker in compounds $\mathbf{2}, \mathbf{3}$, and $\mathbf{4}$ than in compound $\mathbf{1}[22,23]$, the lower polymer yield obtained with 2,3, and 5, at least under thermal activation conditions, cannot be attributed to a reduced primary radical flux. Rather, it appears that the $\mathrm{CHF}_{2}{ }^{\bullet}, \mathrm{CF}_{3} \mathrm{CH}_{2}{ }^{\bullet}$, and $\mathrm{CH}_{3} \mathrm{CF}_{2}{ }^{\bullet}$ radicals (the latter being generated after decarbonylation of 5 to form 4 in situ) are not able to efficiently add to VDF.

The ${ }^{19} \mathrm{~F}$ NMR spectra of the recovered PVDF products display the usual features in terms of the monomer addition mode. Those obtained with initiation by photolytic activation of 2 (visible light, entry 2, Table 4, Figure S15, UV light, entry 3, Figure S16) show the presence of residual 2 in the polymer (resonance at $\delta-71.6 \mathrm{ppm}$ ), [23] particularly for the visible light irradiation experiment, which indicates a slow $\mathrm{Mn}-\mathrm{CHF}_{2}$ bond photocleavage. Clearly, the efficiency of this process does not correlate with the BDE because the Mn- $\mathrm{R}_{\mathrm{F}}$ bond is weaker for $\mathbf{2}$ than for $\mathbf{1}$, whereas compound $\mathbf{1}$ is a quite efficient photo-initiator (vide supra). A relatively intense resonance at $\delta-114.4 \mathrm{ppm}$ is assigned to the $\mathrm{CHF}_{2}$ chain-ends. Integration of this signal relative to the main PVDF resonance indicates that the obtained product is an oligomer with 8 monomer units. This result is similar for entries 2 and 3. This chain end likely corresponds to the primary radical produced by the initiator because there is no reason why the $\mathrm{H}$ atom transfer from $\mathrm{DMC}$ onto the $\mathrm{PVDF}_{\mathrm{H}}$ macroradical, which leads to the same function, would be more frequent for the 2 -initiated polymerization than for that initiated by 1 ( $c f$. with the intensity of the same resonance in Figures S12 and S14). In addition, two more resonances were detected in the sample and resulted from the visible light activation (Figure S15) at $\delta-75.9$ and $-74.7 \mathrm{ppm}$. These may correspond to a PVDF-CH $=\mathrm{CF}_{2}$ chain-end ( $c f . \delta-72.2$ and $-73.4 \mathrm{ppm}$ vs. acetone- $d_{6}$ according to a previous report) [40]. 
Table 4. Experimental conditions and results of the polymerization of VDF $(1.5 \mathrm{~g})$ in the presence of $\left[\mathrm{Mn}\left(\mathrm{R}_{\mathrm{F}}\right)(\mathrm{CO})_{5}\right]$ initiators.

\begin{tabular}{|c|c|c|c|c|c|c|c|}
\hline Entry & Complex & Activation Method & Reaction Time (h) & Yield $^{a}(\%)$ & {$[\mathrm{VDF}] /\left[\mathrm{Mn}(\mathrm{CO})_{5} \mathrm{R}_{\mathrm{F}}\right]$} & $M_{n}^{b}\left(g \cdot \mathrm{mol}^{-1}\right)$ & $\mathbf{D}$ \\
\hline 1 & 2 & Thermal $\left(80^{\circ} \mathrm{C}\right)$ & 24 & 0 & 50 & - & - \\
\hline 2 & 2 & hv (visible light) & 24 & 2 & 50 & ND & ND \\
\hline 3 & 2 & $\mathrm{~h} v(\mathrm{UV} 300 \mathrm{~nm})$ & 24 & 5 & 50 & ND & ND \\
\hline 4 & 3 & Thermal $\left(90^{\circ} \mathrm{C}\right)$ & 24 & 2 & 50 & 32,200 & 1.11 \\
\hline 5 & 3 & Thermal $\left(90^{\circ} \mathrm{C}\right)$ & 24 & 3 & 100 & 32,200 & 1.16 \\
\hline 6 & 3 & Thermal $\left(100^{\circ} \mathrm{C}\right)$ & 24 & 3 & 100 & 31,600 & 1.15 \\
\hline 7 & 5 & Thermal $\left(80^{\circ} \mathrm{C}\right)$ & 24 & 7 & 50 & 16,200 & 1.38 \\
\hline 8 & 5 & hv (visible light) & 4 & 3 & 50 & 12,600 & 1.48 \\
\hline 9 & 5 & hv (visible light) & 8 & 8 & 50 & 22,500 & 1.44 \\
\hline 10 & 5 & hv (visible light) & 12 & 13 & 50 & 24,000 & 1.40 \\
\hline 11 & 5 & hv (visible light) & 24 & 23 & 50 & 23,000 & 1.45 \\
\hline 12 & 5 & $\mathrm{~h} v(\mathrm{UV} 300 \mathrm{~nm})$ & 4 & 16 & 50 & 11,100 & 1.57 \\
\hline 13 & 5 & $\mathrm{~h} v$ (UV $300 \mathrm{~nm}$ ) & 8 & 18 & 50 & 10,000 & 1.69 \\
\hline 14 & 5 & $\mathrm{~h} v(\mathrm{UV} 300 \mathrm{~nm})$ & 12 & 20 & 50 & 9500 & 1.81 \\
\hline 15 & 5 & hv (UV $300 \mathrm{~nm})$ & 24 & 21 & 50 & 7000 & 1.94 \\
\hline
\end{tabular}

a Determined from the mass of the obtained polymer. ${ }^{b}$ Calculated by SEC in DMF by a refractive index (calibrated with PMMA standards). ND stands for "not determined." 
For the PVDF generated by thermal initiation with compound 3, no initiator resonances (e.g., the ${ }^{19} \mathrm{~F}$ NMR resonance, which is expected at $\delta-52.3 \mathrm{ppm}$ ) [23] were evident in the spectra of the isolated polymer (Figures S17 and S18). Thus, the initiator was fully activated under these conditions. No photoactivation experiments were carried out with this compound. The $\mathrm{CF}_{3} \mathrm{CH}_{2}$ - chain end was highlighted by a small resonance at $\delta-60.8 \mathrm{ppm}$ in the ${ }^{19} \mathrm{~F}$ NMR spectrum (Figure S18). Compound 5 was also fully activated under thermal conditions since ${ }^{19} \mathrm{~F}$ NMR resonances attributable to either 5 or to its decarbonylation product 4 (expected at $\delta-91.5$ and $-28.9 \mathrm{ppm}$, respectively) [23] were not detected (Figure S19).

\subsection{Copolymerization of Vinyl Acetate with tert-Butyl 2-(Trifluoromethyl)acrylate Initiated by Complexes 3 and 6}

The aim of these investigations was to check the initiation capacity by using more reactive monomers of the complexes that do not efficiently initiate the VDF polymerization. For the purpose of this study, in addition to complex 3 , the acyl complex $\left[\mathrm{Mn}\left(\mathrm{COCHF}_{2}\right)(\mathrm{CO})_{5}\right](6)$, which generates complex 2 by thermal decarbonylation in situ was used instead of the isolated $\mathbf{2}$. Four co-polymerizations of vinyl acetate (VAc) and tert-butyl 2-(trifluoromethyl)acrylate (MAF-TBE) were carried out using compounds 3 and $\mathbf{6}$ as initiators (Scheme 2). This copolymer was previously synthesized by conventional [41] OMRP using cobalt(II) acetylacetonate as a controlling agent [42] and RAFT polymerization [43]. All these four co-polymerizations led to copolymers, which display a perfectly alternating structure, in agreement with the measured reactivity ratios that are both close to zero [41]. The copolymerizations were carried out only with thermal initiation and the results are collected in Table 5.

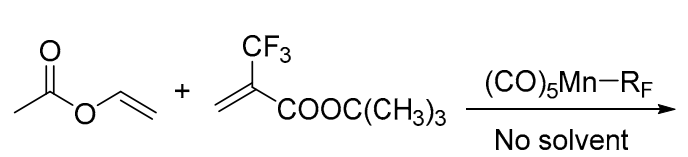

VAC

\section{MAF-TBE}<smiles>[R]C(C)(C)C(CC(C)(C(=O)OC)C([X])(C)F)OC(C)=O</smiles>

$$
\mathrm{R}_{\mathrm{F}}=\mathrm{CH}_{2} \mathrm{CF}_{3}, 3
$$
$\mathrm{COCHF}_{2}, 6$

Scheme 2. Alternating copolymerization of VAc and MAF-TBE initiated by the $\left[\mathrm{Mn}\left(\mathrm{CH}_{2} \mathrm{CF}_{3}\right)(\mathrm{CO})_{5}\right]$ (3) and $\left[\mathrm{Mn}\left(\mathrm{COCHF}_{2}\right)(\mathrm{CO})_{5}\right](6)$ complexes. $\mathrm{R}_{\mathrm{F}}$ stands for fluoroalkyl group and $\mathrm{X}$ represents $\mathrm{Mn}(\mathrm{CO})_{5}$ or $\mathrm{H}$ or $\mathrm{R}_{\mathrm{F}}$.

Table 5. Experimental conditions and results of the copolymerization of VAc and MAF-TBE thermally initiated with compounds 6 and 3.

\begin{tabular}{ccccccccc}
\hline Entry & Initiator & $\begin{array}{c}\text { Temperature } \\
\left({ }^{\circ} \mathbf{C}\right)\end{array}$ & $\begin{array}{c}\text { Reaction } \\
\text { Time }(\mathbf{h})\end{array}$ & $\begin{array}{c}{\left[\mathbf{M n}\left(\mathbf{R}_{\mathbf{F}}\right)(\mathbf{C O})_{5}\right]} \\
(\mathbf{m g})\end{array}$ & $\begin{array}{c}\text { Mn:VAc: } \\
\text { MAF-TBE } \\
\text { Molar Ratio }\end{array}$ & $\begin{array}{c}\text { Yield } \\
(\mathbf{\%})\end{array}$ & $\begin{array}{c}\mathbf{M}_{\mathbf{n}} \\
\left(\mathbf{g} \cdot \mathbf{m o l}^{-\mathbf{1}} \mathbf{)}\right.\end{array}$ & $\mathbf{D}$ \\
\hline 1 & $\mathbf{6}$ & 70 & 72 & 53.0 & $1: 50: 50$ & 17 & 58,300 & 1.53 \\
2 & $\mathbf{6}$ & 85 & 3 & 50.5 & $1: 50: 50$ & 38 & 41,300 & 1.43 \\
3 & $\mathbf{3}$ & 70 & 72 & 22.5 & $1: 50: 50$ & 21 & 7000 & 1.69 \\
4 & $\mathbf{3}$ & 80 & 18 & 93.3 & $1: 50: 50$ & 83 & 76,000 & 2.12 \\
\hline
\end{tabular}

The poly(VAc-alt-MAF-TBE) copolymer was obtained in moderate to high yields depending on the reaction temperature, which proves that compounds $\mathbf{3}$ and $\mathbf{6}$ can generate a flux of radicals able to initiate a radical polymerization. It is noted that the temperatures used for these polymerizations are equivalent or lower than that of the corresponding VDF polymerizations (i.e., up to $80^{\circ} \mathrm{C}$ with compound 3 in entry 4 , vs. $100{ }^{\circ} \mathrm{C}$ for the VDF polymerization). The ${ }^{1} \mathrm{H}$ and ${ }^{19} \mathrm{~F}$ NMR spectra (Figures S20 and S21, respectively) of the isolated copolymer (Table 5, entry 4) are in agreement with the previously published ones $[42,44]$ and clearly show the perfect alternation of comonomers since no ${ }^{1} \mathrm{H}$ NMR signal centered at $\delta 4.9 \mathrm{ppm}$ (the typical chemical shift of VAc-VAc dyads) was observed. 


\section{Discussion}

The combined results of this investigation show that compound $\mathbf{1}$ is an efficient initiator for the polymerization of VDF under both thermal $\left(100^{\circ} \mathrm{C}\right)$ and photochemical (visible or UV light irradiation) conditions. This occurs by homolytic cleavage of the $\mathrm{Mn}-\mathrm{CF}_{3}$ bond and generation of $\mathrm{CF}_{3}{ }^{\bullet}$ radicals, which efficiently add onto the VDF tail $\left(\mathrm{CH}_{2}\right)$, as reported in previous studies [32,34,37-39]. The head-end attack was reported to occur at less than $3 \%$ frequency at $150{ }^{\circ} \mathrm{C}$ [37]. On the other hand, the $\mathrm{CHF}_{2}{ }^{\bullet}$ and $\mathrm{CF}_{3} \mathrm{CH}_{2}{ }^{\bullet}$ radicals, generated from compounds 2 and 3 , respectively, and, to a certain extent, the $\mathrm{CH}_{3} \mathrm{CF}_{2}{ }^{\bullet}$ radical released from compound 4 (which is, in turn, generated in situ from compound 5) do not lead to efficient initiation of the VDF polymerization. A lower ability of compounds 2,3 , and 5 to produce enough radical flux can be excluded as a possible alternative explanation for the observed low PVDF yields (Table 4) because experimental and computational studies have shown that the $\mathrm{Mn}-\mathrm{R}_{\mathrm{F}}$ bond is homolytically stronger for $\mathbf{1}$. Therefore, fluoroalkyl radicals can be generated from compounds 2, 3, and 5, and are able to initiate the VDF polymerization. However, the yields of the resulting PVDF were rather low. Furthermore, the acyl precursor $\mathbf{6}$ (which yields $\mathbf{2}$ in situ by thermal decarbonylation) and $\mathbf{3}$ were shown to efficiently initiate the radical alternating copolymerization of VAc and MAF-TBE.

The effect of the radical and alkene substituents on the rate of the addition reaction has received some attention $[45,46]$. As pioneered by Tedder and Walton $[37,45,46]$, Sokolov et al. [47] reported the reactivity of $\mathrm{F}_{3} \mathrm{C}^{\bullet}$ and other perfluorinated radicals onto several fluorinated olefins and ethylene, concluding that the reactivity of $\mathrm{F}_{3} \mathrm{C}^{\bullet}$ decreases with the number of fluorine atoms on the monomer (e.g., addition of $\mathrm{F}_{3} \mathrm{C}^{\bullet}$ onto ethylene is almost 15 times faster than on VDF). However, to the best of our knowledge, there is no quantitative information on the rate of addition of differently substituted radicals such as $\mathrm{CF}_{3}{ }^{\bullet}, \mathrm{CHF}_{2}{ }^{\bullet}, \mathrm{CF}_{3} \mathrm{CH}_{2}{ }^{\bullet}$, and $\mathrm{CH}_{3} \mathrm{CF}_{2}{ }^{\bullet}$ onto the same monomer. The results of our studies were very unexpected because the PVDF- $\mathrm{CH}_{2} \mathrm{CF}_{2}{ }^{\bullet}$ and PVDF- $\mathrm{CF}_{2} \mathrm{CH}_{2}{ }^{\bullet}$ macroradicals can rapidly add onto the VDF molecule, preferentially to the tail end, during the VDF radical propagation step. We can, therefore, conclude that the rate of radical addition onto $\mathrm{CH}_{2}=\mathrm{CF}_{2}$ is strongly affected by the radical substitution and, most importantly, that the $\mathrm{CHF}_{2}{ }^{\bullet}, \mathrm{CF}_{3} \mathrm{CH}_{2}{ }^{\bullet}$, and $\mathrm{CH}_{3} \mathrm{CF}_{2}$ ' radicals cannot be considered as sufficiently good models for the reactivity of the PVDF head and tail macroradicals.

\section{Conclusions}

Fluoroalkylpentacarbonylmanganese(I) complexes are able to initiate the polymerization of VDF and the copolymerization of VAc and MAF-TBE by the homolytic bond cleavage of the Mn- $\mathrm{R}_{\mathrm{F}}$ bond, which releases $R_{F} \cdot$ radicals. In the case of the VDF homopolymerization, the results are different depending on the nature of the $\mathrm{R}_{\mathrm{F}}$ group and on the activation method, which yields PVDF in almost all cases but with different conversions, molar masses, and dispersities. The best results in terms of activation were achieved with $\left[\mathrm{Mn}\left(\mathrm{CF}_{3}\right)(\mathrm{CO})_{5}\right](\mathbf{1})$, with yields up to $74 \%$ from UV irradiation, $68 \%$ by thermal activation, or $60 \%$ by visible light activation. Although this complex has the strongest BDE among all investigated complexes [22,23], the resulting $\mathrm{CF}_{3}{ }^{\bullet}$ radical is the most efficient one for the addition onto the VDF monomer. The second best result was surprisingly obtained with [ $\left.\mathrm{Mn}\left(\mathrm{COCF}_{2} \mathrm{CH}_{3}\right)(\mathrm{CO})_{5}\right]$ (5), which generates the $\mathrm{CH}_{3} \mathrm{CF}_{2} \bullet$ radical, following prior decarbonylation and $\left[\mathrm{Mn}\left(\mathrm{CF}_{2} \mathrm{CH}_{3}\right)(\mathrm{CO})_{5}\right]$ (4) formation. Despite the fact that the latter complex has the lowest predicted $\mathrm{BDE}$ [22], it can initiate the polymerization of VDF in a relatively low yield under visible light and UV irradiation ( $21 \%$ and $23 \%$, respectively). Nevertheless, this complex has a low efficiency in thermal activation at $80{ }^{\circ} \mathrm{C}$. Complexes $\left[\mathrm{Mn}\left(\mathrm{CHF}_{2}\right)(\mathrm{CO})_{5}\right](2)$ and $\left[\mathrm{Mn}\left(\mathrm{CH}_{2} \mathrm{CF}_{3}\right)(\mathrm{CO})_{5}\right](3)$ are not efficient initiators under any of the tested activation conditions. However, these compounds are efficient initiators for the radical alternating copolymerization of VAc with MAF-TBE. Hence, the effect of the substituents on the radicals and their reactivity toward VDF are subtle. While the $\mathrm{CF}_{3}{ }^{\bullet}$ radical is efficient, $\mathrm{CHF}_{2}{ }^{\bullet}, \mathrm{CF}_{3} \mathrm{CH}_{2}{ }^{\bullet}$, and $\mathrm{CH}_{3} \mathrm{CF}_{2}{ }^{\bullet}$ radicals have shown a lower reactivity to be considered as suitable models for initiating the polymerization of VDF. 
Supplementary Materials: The following are available online at http://www.mdpi.com/2073-4360/12/2/384/s1, Figure S1: First-order kinetics plot for the polymerization of VDF initiated by visible light in presence of $\left[\mathrm{Mn}\left(\mathrm{CF}_{3}\right)(\mathrm{CO})_{5}\right]$. Figure S2: First-order kinetics plot for the polymerization of VDF initiated by UV irradiation $(300 \mathrm{~nm})$ in the presence of $\left[\mathrm{Mn}\left(\mathrm{CF}_{3}\right)(\mathrm{CO})_{5}\right]$. Figure S3: SEC traces of PVDF samples obtained by thermal radical polymerization of VDF with $\left[\mathrm{Mn}\left(\mathrm{CF}_{3}\right)(\mathrm{CO})_{5}\right]$ in DMF normalized with conversion (entries 2, 3, 4, and 7 of Table 1). Figure S4: SEC traces of PVDF samples initiated by visible light (entries 9 to 11 of Table 1) in DMF normalized with conversion. Figure S5: SEC traces of PVDF samples initiated by UV irradiation (entries 12 to 14 of Table 1) in DMF normalized with conversion. Figure S6: SEC traces of PVDF samples (entries 7, 11, and 14 of Table 1) in DMF after 24 h-reaction by various initiation methods. Figure S7: Plot of the number of average molar mass and dispersity vs. conversion of VDF polymerization initiated thermally $\left(100{ }^{\circ} \mathrm{C}\right)$ by complex 1 . Figure S8: Plot of the number of average molar mass and dispersity vs. conversion of VDF polymerization initiated by complex 1 under visible light irradiation. Figure S9: ${ }^{1} \mathrm{H}$ NMR spectrum $\left(400 \mathrm{MHz}, \mathrm{DMF}-d_{7}\right)$ of the PVDF obtained by thermal activation of 1 (entry 7 of Table 1). Figure S10: ${ }^{19} \mathrm{~F}$ NMR spectrum $\left(376.5 \mathrm{MHz}, \mathrm{DMF}-d_{7}\right)$ of the PVDF obtained by thermal activation of 1 (entry 5 in Table 1). Figure S11: ${ }^{1} \mathrm{H}$ NMR spectrum (400 MHz, DMSO- $d_{6}$ ) of the PVDF obtained by visible light activation of 1 (entry 11 of Table 1). Figure S12: ${ }^{19} \mathrm{~F}$ NMR spectrum $\left(376.5 \mathrm{MHz}, \mathrm{DMSO}-d_{6}\right)$ of the PVDF obtained by visible light activation of 1 (entry 11 of Table 1). Figure S13: ${ }^{1} \mathrm{H}$ NMR spectrum $(400 \mathrm{MHz}$, DMF- $d_{7}$ ) of the PVDF obtained by UV light activation of 1 (entry 14 of Table 1 ). Figure S14: ${ }^{19}$ F NMR spectrum (376.5 MHz, DMF- $d_{7}$ ) of the PVDF obtained by UV light activation of 1 (entry 14 of Table 1). Figure S15: ${ }^{19} \mathrm{~F}$ NMR spectrum (376.5 MHz, DMF- $d_{7}$ ) of the PVDF obtained by visible activation of 2 (entry 2 of Table 4 ). Figure S16: ${ }^{19} \mathrm{~F}$ NMR spectrum (376.5 MHz, DMF- $d_{7}$ ) of the PVDF obtained by UV activation of 2 (entry 3 of Table 4). Figure S17: ${ }^{1} \mathrm{H}$ NMR spectrum (400 MHz, acetone- $d_{6}$ ) of the PVDF obtained by thermal activation of 3 (entry 6 of Table 4 ). Figure S18: ${ }^{19} \mathrm{~F}$ NMR spectrum $\left(376.5 \mathrm{MHz}\right.$, acetone- $d_{6}$ ) of the PVDF obtained by thermal activation of 3 (entry 6 of Table 4). Figure S19: ${ }^{19} \mathrm{~F}$ NMR spectrum (376.5 MHz, DMSO- $d_{6}$ ) of the PVDF obtained by thermal activation of 5 (entry 7 of Table 4 ). Figure S20: ${ }^{1} \mathrm{H}$ NMR spectrum $\left(400 \mathrm{MHz}\right.$, acetone- $d_{6}$ ) of the poly(VAc-alt-MAF-TBE) obtained by thermal activation of 3 (entry 4 of Table 5). The starred resonance is due to the solvent. Figure S21: ${ }^{19} \mathrm{~F}$ NMR spectrum $\left(376.5 \mathrm{MHz}\right.$, acetone- $d_{6}$ ) of the poly(VAc-alt-MAF-TBE) obtained by thermal activation of 3 (entry 4 of Table 5).

Author Contributions: Conceptualization, R.P. and B.A. Methodology, V.L. and B.A. Investigation R.M.-C. Writing-original draft preparation, R.M.-C. and B.A. Writing-review and editing, R.M.-C., V.L., F.G., C.F., R.P., and B.A. Visualization, R.M.-C. Supervision, V.L., F.G., R.P., and B.A. Project administration, R.P. Funding acquisition, R.P. All authors have read and agreed to the published version of the manuscript.

Funding: The Agence Nationale de la Recherche (ANR, French National Agency) through the FLUPOL project (grant No. ANR-14-CE07-0012) funded this research. We also gratefully acknowledge additional financial support from the Centre National de la Recherche Scientifique (CNRS).

Acknowledgments: We thank P. Falireas for his assistance and Arkema (Pierre-Bénite, France) and Tosoh Finechem Corp. (Shunan, Japan) for supplying free samples of VDF and MAF-TBE, respectively.

Conflicts of Interest: The authors declare no conflict of interest.

\section{References}

1. Ameduri, B. From Vinylidene Fluoride (VDF) to the Applications of VDF-Containing Polymers and Copolymers: Recent Developments and Future Trendst. Chem. Rev. 2009, 109, 6632-6686. [CrossRef]

2. Martins, P.; Lopes, A.C.; Lanceros-Mendez, S. Electroactive phases of poly(vinylidene fluoride): Determination, processing and applications. Prog. Polym. Sci. 2014, 39, 683-706. [CrossRef]

3. Asandei, A.D. Photomediated Controlled Radical Polymerization and Block Copolymerization of Vinylidene Fluoride. Chem. Rev. 2016, 116, 2244-2274. [CrossRef]

4. Goldbach, J.T.; Amin-Sanayei, R.; He, W.; Henry, J.; Kosar, W.; Lefebvre, A.; O’Brien, G.; Vaessen, D.; Wood, K.; Zerafati, S. Chapter 6 Commercial Synthesis and Applications of Poly(Vinylidene Fluoride). In Fluorinated Polymers: Volume 2; Applications, A.B., Sawada, H., Eds.; The Royal Society of Chemistry: London, UK, 2017; Volume 2, pp. 127-157.

5. Golzari, N.; Adams, J.; Beuermann, S. Inducing $\beta$ Phase Crystallinity in Block Copolymers of Vinylidene Fluoride with Methyl Methacrylate or Styrene. Polymer 2017, 9, 306. [CrossRef]

6. Guiot, J.; Ameduri, B.; Boutevin, B. Radical homopolymerization of vinylidene fluoride initiated by tert-butyl peroxypivalate. Investigation of the microstructure by $19 \mathrm{~F}$ and $1 \mathrm{H}$ NMR spectroscopies and mechanisms. Macromolecules 2002, 35, 8694-8707. [CrossRef] 
7. Mladenov, G.; Ameduri, B.; Kostov, G.; Mateva, R. Synthesis and characterization of fluorinated telomers containing vinylidene fluoride and hexafluoropropene from 1,6-diiodoperfluorohexane. J. Polym. Sci. Part A Polym. Chem. 2006, 44, 1470-1485. [CrossRef]

8. Pladis, P.; Alexopoulos, A.H.; Kiparissides, C.; Pladis, P. Mathematical Modeling and Simulation of Vinylidene Fluoride Emulsion Polymerization. Ind. Eng. Chem. Res. 2014, 53, 7352-7364. [CrossRef]

9. Tatemoto, M. In Proceedings of the First Regular Meeting of Soviet-Japanese Fluorine Chemists, Tokyo, Japan, 14-15 February 1979.

10. Boyer, C.; Valade, D.; Sauguet, L.; Ameduri, B.; Boutevin, B. Iodine Transfer Polymerization (ITP) of Vinylidene Fluoride (VDF). Influence of the Defect of VDF Chaining on the Control of ITP. Macromolecules 2005, 38, 10353-10362. [CrossRef]

11. Beuermann, S.; Imran-Ul-Haq, M. Homogeneous Phase Polymerization of Vinylidene Fluoride in Supercritical CO2: Surfactant Free Synthesis and Kinetics. Macromol. Symp. 2007, 259, 210-217. [CrossRef]

12. Imran-ul-haq, M.; Förster, N.; Vukicevic, R.; Herrmann, K.; Siegmann, R.; Beuermann, S. Chapter 15: Iodine Transfer Radical Polymerizations of Vinylidene Fluoride in Supercritical Carbon Dioxide and Polymer Functionalization via Click Chemistry. In Controlled/Living Radical Polymerization: Progress in RAFT, DT, NMP $\mathcal{E} O M R P$; Matyjaszewski, K., Ed.; ACS: Washington, DC, USA, 2009; Volume 1024, pp. 233-243.

13. Asandei, A.D.; Adebolu, O.I.; Simpson, C.P. Mild-Temperature Mn2(CO)10-Photomediated Controlled Radical Polymerization of Vinylidene Fluoride and Synthesis of Well-Defined Poly(vinylidene fluoride) Block Copolymers. J. Am. Chem. Soc. 2012, 134, 6080-6083. [CrossRef]

14. Guerre, M.; Campagne, B.; Gimello, O.; Parra, K.; Ameduri, B.; Ladmiral, V. Deeper Insight into the MADIX Polymerization of Vinylidene Fluoride. Macromolecules 2015, 48, 7810-7822. [CrossRef]

15. Guerre, M.; Rahaman, S.M.W.; Améduri, B.; Poli, R.; Ladmiral, V. Limits of Vinylidene Fluoride RAFT Polymerization. Macromolecules 2016, 49, 5386-5396. [CrossRef]

16. Banerjee, S.; Ladmiral, V.; Debuigne, A.; Detrembleur, C.; Poli, R.; Améduri, B. Organometallic-Mediated Radical Polymerization of Vinylidene Fluoride. Angew. Chem. Int. Ed. 2018, 57, 2934-2937. [CrossRef]

17. Falireas, P.G.; Ladmiral, V.; Debuigne, A.; Detrembleur, C.; Poli, R.; Ameduri, B. Straightforward Synthesis of Well-Defined Poly(vinylidene fluoride) and Its Block Copolymers by Cobalt-Mediated Radical Polymerization. Macromolecules 2019, 52, 1266-1276. [CrossRef]

18. Debuigne, A.; Poli, R.; Jérôme, C.; Jerôme, R.; Detrembleur, C. Overview of cobalt-mediated radical polymerization: Roots, state of the art and future prospects. Prog. Polym. Sci. 2009, 34, 211-239. [CrossRef]

19. Poli, R. New Phenomena in Organometallic-Mediated Radical Polymerization (OMRP) and Perspectives for Control of Less Active Monomers. Chem. Eur. J. 2015, 21, 6988-7001. [CrossRef]

20. Debuigne, A.; Jérôme, C.; Detrembleur, C. Organometallic-mediated radical polymerization of 'less activated monomers': Fundamentals, challenges and opportunities. Polymer 2017, 115, 285-307. [CrossRef]

21. Fliedel, C.; Poli, R. Homolytically weak metal-carbon bonds make robust controlled radical polymerizations systems for "less-activated monomers. "J. Organomet. Chem. 2019, 880, 241-252. [CrossRef]

22. Poli, R.; Rahaman, S.; Ladmiral, V.; Améduri, B. Effect of $\alpha$ - and $\beta-\mathrm{H} / \mathrm{F}$ substitution on the homolytic bond strength in dormant species of controlled radical polymerization: OMRP vs. ITP and RAFT. J. Organomet. Chem. 2018, 864, 12-18. [CrossRef]

23. Morales-Cerrada, R.; Fliedel, C.; Daran, J.-C.; Gayet, F.; Ladmiral, V.; Améduri, B.; Poli, R. Fluoroalkyl Radical Generation by Homolytic Bond Dissociation in Pentacarbonylmanganese Derivatives. Chem. Eur. J. 2019, 25, 296-308. [CrossRef]

24. Nakagawa, K.; Ishida, Y. Annealing effects in poly(vinylidene fluoride) as revealed by specific volume measurements, differential scanning calorimetry, and electron microscopy. J. Polym. Sci. Part A-2 Polym. Phys. 1973, 11, 2153-2171. [CrossRef]

25. Morales-Cerrada, R.; Fliedel, C.; Gayet, F.; Ladmiral, V.; Améduri, B.; Poli, R. Thermal Decomposition of Fluoroalkyl Pentacarbonylmanganese(I) Derivatives by $\alpha$-Fluorine Elimination. Organometallics 2019, 38, 1021-1030. [CrossRef]

26. Fawcett, J.P.; Poe, A.; Sharma, K.R. Reaction mechanisms of metal-metal bonded carbonyls. X. Thermal decomposition of decacarbonyldimanganese and decacarbonylmanganeserhenium in decalin. J. Am. Chem. Soc. 1976, 98, 1401-1407. [CrossRef]

27. Aliwi, S.M.; Bamford, C.H.; Mullik, S.U. Recent studies in photoinitiated polymerization. J. Polym. Sci. Part C 1975, 50, 33-50. [CrossRef] 
28. Allan, L.E.; Perry, M.R.; Shaver, M.P. Organometallic mediated radical polymerization. Prog. Polym. Sci. 2012, 37, 127-156. [CrossRef]

29. Destarac, M.; Matyjaszewski, K.; Silverman, E.; Ameduri, B.; Boutevin, B. Atom Transfer Radical Polymerization Initiated with Vinylidene Fluoride Telomers. Macromolecules 2000, 33, 4613-4615. [CrossRef]

30. Girard, E.; Marty, J.-D.; Ameduri, B.; Destarac, M. Direct Synthesis of Vinylidene Fluoride-Based Amphiphilic Diblock Copolymers by RAFT/MADIX Polymerization. ACS Macro Lett. 2012, 1, 270-274. [CrossRef]

31. Duc, M.; Ameduri, B.; Boutevin, B.; Kharroubi, M.; Sage, J.M. Telomerization of vinylidene fluoride with methanol. Elucidation of the reaction process and mechanism by a structural analysis of the telomers. Macromol. Chem. Physic. 1998, 199, 1271-1289. [CrossRef]

32. Boschet, F.; Ono, T.; Ameduri, B. Novel Source of Trifluoromethyl Radical As Efficient Initiator for the Polymerization of Vinylidene Fluoride. Macromol. Rapid Commun. 2012, 33, 302-308. [CrossRef]

33. Pianca, M.; Barchiesi, E.; Esposto, G.; Radice, S. End groups in fluoropolymers. J. Fluor. Chem. 1999, 95, 71-84. [CrossRef]

34. Ameduri, B.; Ladaviere, C.; Delolme, F.; Boutevin, B. First MALDI-TOF Mass Spectrometry of Vinylidene Fluoride Telomers Endowed with Low Defect Chaining. Macromolecules 2004, 37, 7602-7609. [CrossRef]

35. Kim, J.-S.; Dutta, A.; Vasu, V.; Adebolu, O.I.; Asandei, A.D. Universal Group 14 Free Radical Photoinitiators for Vinylidene Fluoride, Styrene, Methyl Methacrylate, Vinyl Acetate, and Butadiene. Macromolecules 2019, 52, 8895-8909. [CrossRef]

36. Mattern, D.E.; Lin, F.T.; Hercules, D.M. Laser mass spectrometry of poly(fluoroethylenes). Anal. Chem. 1984, 56, 2762-2769. [CrossRef]

37. Tedder, J.M.; Walton, J.C. The kinetics and orientation of free-radical addition to olefins. Acc. Chem. Res. 1976, 9, 183-191. [CrossRef]

38. Dolbier, W.R. Structure, Reactivity, and Chemistry of Fluoroalkyl Radicals. Chem. Rev. 1996, 96, $1557-1584$. [CrossRef]

39. Dolbier, W.R.; Duan, J.-X.; Abboud, K.; Ameduri, B. Synthesis and Reactivity of a Novel, Dimeric Derivative of Octafluoro[2.2]paracyclophane. A New Source of Trifluoromethyl Radicals. J. Am. Chem. Soc. 2000, 122, 12083-12086. [CrossRef]

40. Otazaghine, B.; Sauguet, L.; Ameduri, B. Synthesis and copolymerisation of fluorinated monomers bearing a reactive lateral group Part 21. Radical copolymerisation of vinylidene fluoride with 2-hydroperfluorooct-1-ene. J. Fluor. Chem. 2005, 126, 1009-1016. [CrossRef]

41. Banerjee, S.; Ladmiral, V.; Totée, C.; Améduri, B. Alternating radical copolymerization of vinyl acetate and tert-butyl-2-trifluoromethacrylate. Eur. Polym. J. 2018, 104, 164-169. [CrossRef]

42. Banerjee, S.; Ladmiral, V.; Debuigne, A.; Detrembleur, C.; Rahaman, S.M.W.; Poli, R.; Ameduri, B. Organometallic-Mediated Alternating Radical Copolymerization of tert -Butyl-2-Trifluoromethacrylate with Vinyl Acetate and Synthesis of Block Copolymers Thereof. Macromol. Rapid Commun. 2017, 38. [CrossRef]

43. Banerjee, S.; Guerre, M.; Ameduri, B.; Ladmiral, V. Syntheses of 2-(trifluoromethyl)acrylate-containing block copolymers via RAFT polymerization using a universal chain transfer agent. Polym. Chem. 2018, 9, 3511-3521. [CrossRef]

44. Banerjee, S.; Bellan, E.V.; Gayet, F.; Debuigne, A.; Detrembleur, C.; Poli, R.; Améduri, B.; Ladmiral, V. Bis (formylphenolato)cobalt(II)-Mediated Alternating Radical Copolymerization of tert-Butyl 2-Trifluoromethylacrylate with Vinyl Acetate. Polymers 2017, 9, 702. [CrossRef]

45. Tedder, J.M.; Walton, J.C. The Importance of Polarity and Steric Effects in Determining the Rate and Orientation of Free-Radical Addition to Olefins-Rules for Determining the Rate and Preferred Orientation. Tetrahedron 1980, 36, 701-707. [CrossRef]

46. Tedder, J.M. Which Factors Determine the Reactivity and Regioselectivity of Free Radical Substitution and Addition Reactions? Angew. Chem. Int. Ed. 1982, 21, 401-410. [CrossRef]

47. Serov, S.I.; Zhuravlev, M.V.; Sass, V.P.; Sokolov, S.V. Reactions of fluoro-containing free radicals in solution. II. Kinetics of the addition of perfluoroalkyl radicals to olefins in heptane. J. Org. Chem. USSR 1981, 17, 53-58. 